\title{
The Effect of CSR Disclosure On Firm Risk In Mining Companies Listed On IDX
}

\author{
Sayu Aryantini Thanaya ${ }^{1}$ \\ Faculty of Economics and Business \\ Udayana University, Indonesia. \\ Email: sayuaryantini@yahoo.com
}

\author{
A. A. G. P. Widanaputra ${ }^{2}$ \\ Faculty of Economics and Business \\ Udayana University, Indonesia
}

\begin{abstract}
This research aims to obtain empirical evidence on the effect of corporate social responsibility disclosure on firm risk. This research was conducted on mining companies listed on Indonesia Stock Exchange in 2015-2017. The sample determination method is purposive sampling, with 109 observations. The data analysis technique used is simple linear regression analysis. Based on the research results, it is known that corporate social responsibility disclosure has a negative effect on firm risk. This means that the more CSR disclosure of a company, the lower the firm risk. The implications of the research results supports the signaling theory, stakeholder theory, and legitimacy theory, where risk management efforts are done by sending positive signals through the disclosure of CSR information, to gain the support and trust from the company's stakeholders, and increase the organization's legitimacy. On the other hand, this research provides additional information for all company stakeholders in making decisions.
\end{abstract}

Keywords : $\quad$ CSR Disclosure; Firm Risk; Mining.

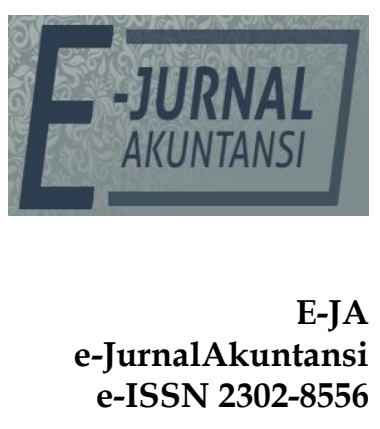

Vol. 29 No. 2

Denpasar, November

2019

Hal. 577-591

Artikel masuk:

30 Agustus 2019

Tanggal diterima:

11 November 2019 


\section{INTRODUCTION}

The capital market in Indonesia is known as Indonesia Stock Exchange (IDX). Among the 10 sectors listed on IDX, the stock price index of the mining sector is considered volatile. Fluctuations in the price of the mining sector stock index can indicate that the realization of stock returns is not in line with the expected return. These fluctuations reflect uncertainty that results in risk for the firms and market participants.

Firm risk is the uncertainty of a company's operations in the future. Risk can be interpreted as a possible occurrence of adverse consequences or undesirable losses(Ghozali, 2013). The sustainability of the company compared to other companies in the market can be reflected by firm risk. Firm risk is measured and identified as total risk. Jo, Kim, \& Park (2016) stated that the total risk of a firm, is the daily stock returns standard deviation over a period of one year.

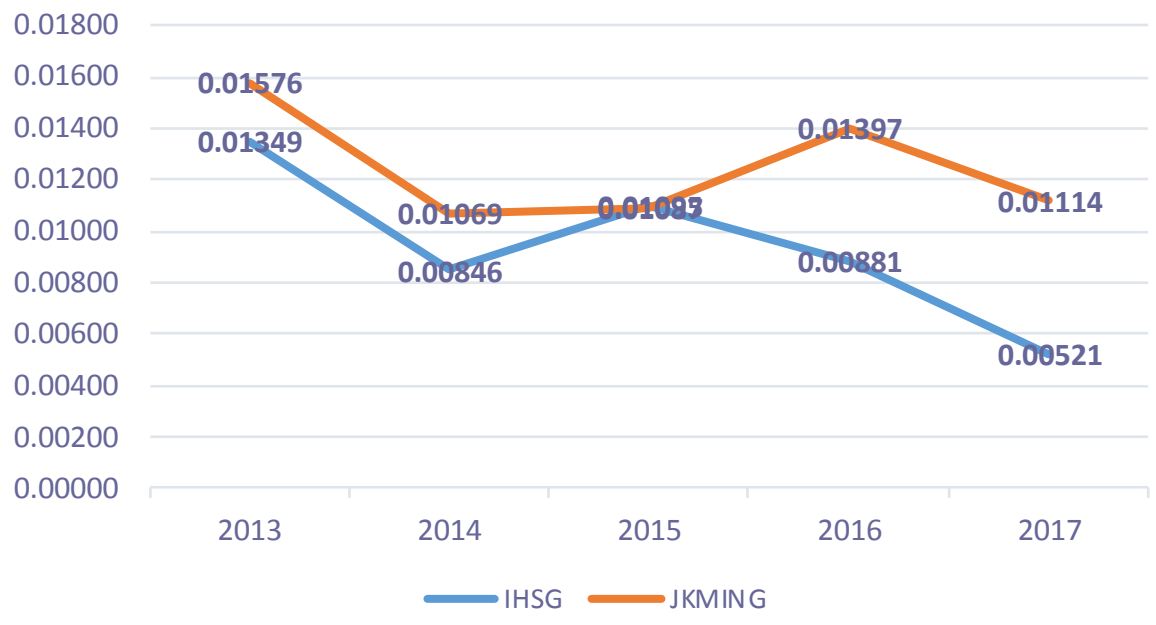

Figure 1. Graph of Standard Deviation Movements of Stock Returns of the Mining sector Index and Composite Stock Price Index (Indeks Harga Saham Gabungan)

Source: www.idx.co.id, 2018

The graph above shows the movement of the standard deviation of the daily stock returns of the Indonesian mining sector index compared to the return of the Indonesian Composite Stock Price Index (market return). Compared to the market returns, the fluctuations of stock returns in the mining sector is. Therefore, it can be said that companies engaged in the mining sector has a relatively high firm risk.

A reason why mining companies have a high risk is because mining companies have operational activities that are closely related to pollution and environmental destruction and exploitation of natural resources, with minimal recovery efforts. This causes the company to obtain a bad reputation, and affects the perceptions and decision making of the company's stakeholders. This may cause uncertainty in the firm's operations, which will affect the sustainability of the company.

In 2017 kompasiana.com reported a case, where the North Kalimantan Mining Advocacy Network (JATAM KALTARA) reported the mining activities 
of PT Mitrabara Adiperdana (MBAP) and its subsidiary company PT Baradinamika Muda Sukses (BDMS) which caused losses to the Malinau community, because the companies disposed the mining operational waste into the rivers around the Malinau area, which had an impact on the community's distribution of clean water.The North Kalimantan Department of Energy and Mineral Resources ordered the companies to comply with the applicable rules and regulations related to mining, to be responsible for its operational activities, and to resolve problems with the community within the specified time period. If the companies do not heed the order, the company's operating permit will be revoked.This case shows that if a mining companies do not pay attention to social and environmental aspects, the company's operating permit may berevoked by the local authority.

In effort to maintain the firm's going concern, mining companies are required to provide feedback and accountability to stakeholders, which brought up the Corporate Social Responsibility (CSR) term. Corporate social responsibility is the process of communicating social and environmental effects of company economic actions in certain societal groups and in society as a whole (Gray, Owen, \& Maunders, 1988). The concept by John Elkington (1998), namely The Triple Bottom Line states that in order for companies to maintain their survival, companies must pay attention to 3P, namely Profit, Planet, and People. In Indonesia, the CSR phenomenon is still undergoing development which shows there is still a low understanding and awareness of CSR implementation in companies (Anjani \& Astika, 2018). Companies whose operations are related to natural resources must implement CSR activities, and this is regulated by the Government of Indonesia inUndang-Undang No. 40 year 2007.

Disclosure of environmental, social and economic performance in the annual report can explain the level of accountability, responsibility and corporate transparency to stakeholders (Prakasa \& Astika, 2017). Disclosure of CSR is captured as a positive signal or good news which can lead to the increase in stock trading activities (Astuti \& Nugrahanti, 2015). Wulandari \& Putri (2014) stated that the higher the level of CSR information, the higher the company's stock returns. Disclosure of CSR is considered to emphasize a firm's brand differentiation, a mean to obtain license to operate both from the government and society, and as a risk management strategy (Suharto, 2007).

Research by Jo \& Na (2012) found a significant negative association between CSR engagement and firm risk in controversial firms, which found that by engaging in various strategic and/ or socially responsible CSR programs, firms can reduce firm risk and subsequently enhances corporate image. The result of this research is in line with the research conducted by Salama et al (2011)., Albuquerqueet al. (2014), Joet al.(2016), Cai et al. (2016), that found a negative relationship between CSR and firm risk. In contrast, the research conducted by Nguyen \& Nguyen (2015) a positive relationship found between CSR and firm risk, where higher risk is associated with CSR strengths related to diversity and employee relations. The positive relationship between CSR and firm risk focuses on the inherent conflict between the interests of employees and shareholders. Barnea\& Rubin (2010) also found a positive relationship between 
CSR and firm risk, where investment in CSR diverts valuable corporate resources can be used in other projects such as developing new product lines or building stronger research and development capabilities. As a result, CSR activities can reduce the competitiveness of companies and make companies more vulnerable to external shocks.

This research is expected to theoretically provide empirical evidence regarding the signaling theory, stakeholder theory, and legitimacy theory in explaining the relationship between corporate social responsibility disclosure and firm risk, and can be an additional references for future research related to corporate social responsibility and firm risk. Practically, the result of this research is expected to provide information to companies, shareholders and stakeholders, regarding the importance of disclosure of corporate social responsibility and its implication on a firm risk.

The signaling theory describes behavior when two parties have access to different information. The signal sender, must choose how and whether to deliver (or signal) information, the signal receiver, must choose how to interpret the signal (Connelly et al., 2011). The purpose of voluntary information disclosure is that company owners hope that the information can be interpreted as a positive signal about company's performance and increase the reputation and value of the company. The signaling theory states that a good quality company will intentionally send signals to the market, with expectations that the market will be able to distinguish between good and bad quality companies (Karlina \& Widanaputra, 2016). The signaling theory is an alternative theoretical lens that can reveal how CSR contributes to corporate financial performance, and how CSR practices may signal the unobserved qualities of firms to relevant stakeholders (Su et al., 2016).

Florea \& Florea(2013) stated "Stakeholders are the persons, institutions, organizations, formal and non-formal groups which are interested or can be affected or which could influence the company decisions or actions. Companies must pay attention to their stakeholders, because the stakeholders can influence and be influenced by the activities and policies that are implemented by the company (Dwipayadnya et al., 2015). Therefore, CSR activities and disclosures are used as a means of corporate accountability, to obtain support from its stakeholders, especially groups that are very concerned about issues of corporate social and environmental impacts (Sembiring, 2003).

Legitimacy theory is based on the notion that companies must act within the bounds of what society deems to be socially acceptable behavior, in order to continue to operate successfully (Jupe, 2005). Companies are more likely to be granted a social license to operate (SLO) and/or organizational legitimacy if they provide society friendly initiatives (Cui et al., 2017). The public will give a positive reaction to the company because the disclosure of CSR activities shows the level of company compliance with prevailing norms, as well as public expectations of the company (Branco \& Rodrigues, 2008). To gain recognition and potential support from various stakeholders, risk reduction through CSR can prove to be an important legitimization mechanism (Cai et al., 2016).

Activities carried out by companies cannot be separated from the risk. According to Brigham \& Houston (2013) the risk of a firm is the uncertainty 
regarding projections of future returns. Firm risk is the uncertainty of a company's operations in the future (Gunawan \& Juniarti, 2014). Risk can be defined as the volatility, or fluctuations in securities returns of a certain company. High firm risk, can lead to conditions of high uncertainty. Firm risk can be identified as total risk. A firm's inherent risk that is a result of external or internal factors that can affect a firm's profitability can be defined as a firm's total risk (Jo \& Na, 2012). Total risk is the combination of systematic and unsystematic risk (Ben-Horim \& Levy, 1980). Risks that affect large numbers of assets, are known as systematic risks or market risks. Whilst, risks affect a small number of assets, are known as unsystematic risks or firm-specific unique risks (Ross, Westerfield, \& Jordan, 2011: 411). Managerial behavior differs depending on the level of risk of the company (Halov \& Heider, 2011).

Corporate Social Responsibility Disclosure is the process of communicating the social and environmental consequences of an organization's economic activities towards a special group that has an interest and the community as a whole (Sembiring, 2003). Rahayu et al.(2014) stated that CSR is a company's effort to increase the welfare of its stakeholders by giving attention to economic, social, and environment aspects. Management's ethical concerns and transparent and reliable financial reporting, is reflected through better CSR (Cui et al., 2016). Mining companies have been obliged to implement corporate social responsibility in accordance with regulations issued by the government, namely Undang-Undang No.4 year 2007 on limited liability companies. The long-term survival of a company will depend on how well the company performs, not only looking at the company's financial performance but how the company also contributes positively to the environment and its social environment (Aghashahiet al., 2013).

Dhaliwal et al., (2012) stated that firms consequently become more transparent by investing in CSR activities, to the extent that firms with CSR engagement are more likely to disclose their CSR activities. Cheng et al. (2014) argued that companies will face lower capital constraints with better CSR performance. A company's investment in CSR help to reduce their risk. CSR engagement provides firms with downside protection equivalent to an insurance contract, by generating relational capital between stakeholders (Godfrey, 2005). Sen et al. (2006) asserted that corporate social responsibility creates a goodwill reservoir of that alleviates negative stakeholder assessments.

Improvement in relationships with shareholders, suppliers, creditors and other groups of stakeholders, are expected from CSR activities (Sun et al., 2010). CSR activities can also be used as one of the company's competitive advantages that can increase sales because it can attract consumers (Susianti \& Yasa, 2013). CSR disclosure can also reflect a company's stable performance because the company is able to allocate funds to finance CSR activities. The stability of the company can reflect the low risks that may be experienced by the company in the future.

Based on the previous literature reviews and the results of previous studies, the conceptual framework in this research can be presented in Figure 2.

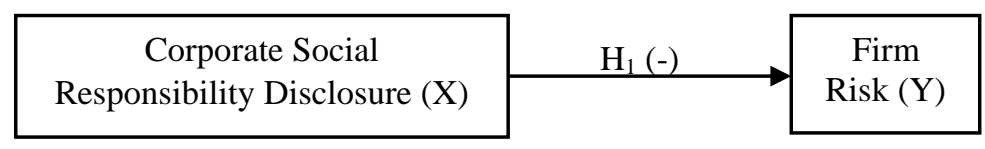




\title{
Figure 2. Conceptual Framework
}

\section{Description:}

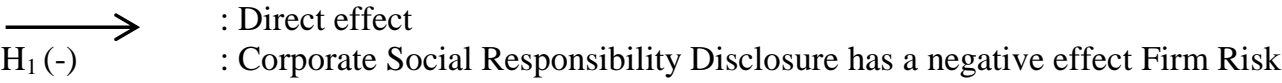

This research discusses the effect of corporate social responsibility disclosure on firm risk. CSR is used by management of companies as a risk management strategy (Suharto, 2007), which can reduce firm risk. The higher the firm risk, the higher the uncertainty of the company's condition in the market, which can be reflected by the level of volatility of the company's stock returns. Firms can reduce their risk by paying attention to economic, social and environmental dimensions, because the sustainability of the company is influenced by the balance between the three aspects. The implementation and disclosure of CSR is used by management as a sign of the company's positive initiative, which is expected to increase the value and reputation of the company in the market. Positive signals conveyed through CSR disclosure are used as an effort to gain support and trust from the company's stakeholders, Through the disclosure of CSR activities in accordance with the prevailing norms and regulations, the company is expected to gain legitimacy from the community, so that the company's operations will be accepted and supported by the community and other stakeholders. Therefore, the increase in corporate social responsibility disclosure is used by management as an effort to manage and reduce firm risk.

The research conducted by Cai et al., (2016), Jo et al., (2016), Albuquerque et al., (2014), Jo \& Na (2012), and Salama et al., (2011) stated that corporate social responsibility has a negative effect on firm risk. Based on the theory and results of the research, the following hypotheses can be formulated:

$\mathrm{H}_{1}$ : The more corporate social responsibility disclosure that is carried out by a company, the lower the firm risk.

\section{RESEARCH METHODS}

This research uses an associative quantitative approach. This research discusses the effect of corporate social responsibility disclosure on firm risk. The research is carried out on mining companies listed on the Indonesia Stock Exchange in 20152017.

The dependent variable in this research is firm risk $(\mathrm{Y})$. Firm risk can be measured by the total risk. Jo et al.(2016) stated that the total risk of a firm can be measured by the standard deviation of daily stock returns over a one-year period. According to Ghozali (2013), standard deviation is a measure of dispersion, or a statistical measure of the risk, where the greater the standard deviation value, the greater the risk. The standard deviation of daily stock returns is formulated:

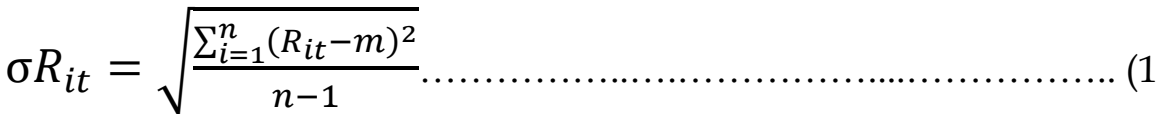

$$
\begin{aligned}
& \text { Where: } R_{i t}=\frac{P_{t}-P_{t-1}}{P_{t-1}} \text { and } \mathrm{m}=\frac{\sum_{n=1}^{n} R_{i t}}{n}
\end{aligned}
$$


Description:

$\sigma R_{i t}=$ Standard deviation of company's daily stock return

$\mathrm{R}_{\text {it }}=$ Company's daily stock return

$\mathrm{m}$ = Company's average daily stock return

$\mathrm{n} \quad=$ Amount of Data

$\mathrm{P}_{\mathrm{t}} \quad=$ Closing Price of company stock at time $\mathrm{t}$

$\mathrm{P}_{\mathrm{t}-1}=$ Closing Price of company stock a day before time $\mathrm{t}$

The independent variable in this research is Corporate Social Responsibility Disclosure (X). The measurement of CSR disclosure refers to the Corporate Social Responsibility Disclosure Index (CSRDI) based on the Global Reporting Initiative (GRI) G4. The GRI G4 standard includes 91 disclosure items. The measurement of this standard is by giving a value of 1 if there is disclosure in accordance with the GRI G4 indicator and a value of 0 if there is no disclosure or the disclosure is not in accordance with the GRI G4 indicator. The formula for calculating CSRDI is as follows:

$$
\mathrm{CSRDI}_{\mathrm{j}}=\frac{\sum X i j}{n}
$$

Description:

$$
\begin{array}{ll}
\text { CSRDI }_{\mathrm{j}} & =\text { Corporate Social Responsibility Disclosure Index } \\
\sum_{\mathrm{n}} & =\text { Amount of disclosure } \\
& =\text { CSRDI disclosure items }
\end{array}
$$

The population in this research is mining companies listed on the Indonesia Stock Exchange from the year 2015 to 2017. The sample of this research is mining companies that were selected using the purposive sampling method and nonprobability sampling technique.

The data used in the research are annual reports and stock prices of mining companies listed on the Indonesia Stock Exchange in 2015-2017. This data was obtained by accessing the official website of the Indonesia Stock Exchange at www.idx.co.id and Yahoo Finance at finance.yahoo.com.

Data analysis technique is a processing technique of the data that has been collected, which will later produce information that is used to answer the problems that have been formulated in this research. The main the data analysis technique used in this research is simple linear regression using the SPSS program. The simple linear regression is based on functional or causal relationships of one independent variable with one dependent variableSugiyono (2017:298). The simple linear regression analysis method in this research is used to determine the effect of corporate social responsibility disclosure on firm risk. The general equation of simple linear regression according to Sugiyono (2017:298) this can be formulated as follows:

$$
\mathrm{Y}=\mathrm{a}+\mathrm{bX}
$$

Description:

$\mathrm{Y}=$ Firm risk

$X=$ Corporate Social Responsibility Disclosure

$a \quad=$ Constant if $X=0$

$\mathrm{b} \quad=$ Independent variable regression coefficient 
From the results of the analysis conducted, the determination coefficient (adjusted $\mathrm{R}^{2}$ ), model feasibility test ( $\mathrm{F}$ test), and hypothesis test ( $\mathrm{t}$ test) can be observed from the research.

\section{RESULTS AND DISCUSSION}

The sample used in this research is 38 companies over a three year period with the total of 109 data observations. The sampling method used in this study is the non-probability method with the purposive sampling technique, which is the technique of determining the sample chosen from the available population using predetermined criteria.The criteria for selecting the research sample are presented in Table 1 below.

Table 1. Sample Selection Results

\begin{tabular}{lc}
\hline \multicolumn{1}{c}{ Criteria } & $\begin{array}{c}\text { Number of } \\
\text { Companies }\end{array}$ \\
\hline The population of this research is mining companies listed on Indonesia & 48 \\
$\begin{array}{l}\text { Stock Exchange in 2015-2017 } \\
1 \quad \text { Mining companies listed on IDX who did not publish their }\end{array}$ & $(8)$ \\
$2 \quad$ annual reports continuously during the year 2015-2017 & $(2)$ \\
Total number of companies in this research & 38 \\
Number of Observation Years & 3 \\
The total observation sample before the reduction of companies' data & 114 \\
with a zero standard deviation of daily stock return value & $(5)$ \\
Companies with a zero standard deviation of daily stock return value & 109 \\
Total research sample & \\
\hline
\end{tabular}

Source: Research Data, 2018

Descriptive statistics in this research explains the characteristics of the sample, mainly including the minimum, maximum, mean, and standard deviation value of each variable. The analysis of the descriptive statistics results of this research can be seen in table 2 below.

Table 2. Descriptive Statistics Results

\begin{tabular}{lrrrrr}
\hline & N & Minimum & Maximum & Mean & Std.Deviation \\
\hline CSR Disclosure & 109 & 0.0330 & 0.9670 & 0.2503 & 0.1381 \\
Firm Risk & 109 & 0.0005 & 0.0820 & 0.0309 & 0.0137 \\
Valid N (listwise) & 109 & & & & \\
\hline
\end{tabular}

Source: Research Data, 2018

Based on Table 2 it can be concluded that the number of observations $(\mathrm{N})$ in this research is 109 . The corporate social responsibility disclosure variable $(X)$ data has the lowest (minimum) value of 0.0330 , the highest (maximum) value of 0.09670 , and the average value of 0.2503 . The standard deviation of the corporate social responsibility disclosure data is 0.1381 . In this research the standard deviation value of the CSR disclosure data is $<2 \bar{X}$, or $0.1381<0.5007$, which means that the data of variable $X$ has a normal distribution.

The firm risk variable $(\mathrm{Y})$ data has the lowest (minimum) value of 0.0005 , the highest (maximum) value of 0,0820 , and the average value of 0.0309 . The standard deviation of the firm risk data is 0.0137 . In this research the standard 
deviation value of the firm risk data is $<2 \bar{Y}$, or $0.0137<0.0618$, which means that the data of variable $Y$ has a normal distribution.

The classic assumption test is needed so that the regression model, which is used as an estimation tool, is not bias, and has fulfilled the basic assumptions in the regression analysis. The classic assumption test conducted consists of the normality test, autocorrelation test, and heteroscedasticity test.

The normality test is used to test whether in the regression model, the data of the dependent variable and the independent variable are both distributed normally. The normality test in this research uses the Kolmogorov-Smirnov test. The result of the normality test of this research is presented in Table 3 below.

Table 3. Normality Test Results

\begin{tabular}{llr}
\hline \multicolumn{3}{c}{ One-Sample Kolmogorov-Smirnov Test } \\
\hline N & \multicolumn{2}{c}{ Unstandardized Residual } \\
\multirow{2}{*}{ Normal Parametersa,b } & Mean & 109 \\
& Std. Deviation & 0,000 \\
\cline { 2 - 3 } Most Extreme Differences & Absolute & 0,013 \\
\cline { 2 - 3 } Test Statistic & Positive & 0,077 \\
Asymp. Sig. (2-tailed) & Negative & 0,077 \\
\hline
\end{tabular}

Source: Research Data, 2018

The research data is said to be normally distributed if the value of the Asymp. Sig. (2-tailed) of the one-sample kolmogorov-smirnovtest is greater than $a=0.05$. Based on Table 3, the value of Asymp. Sig. (2-tailed) from the tested equation model is 0.116 , which is greater than 0.05 . This shows that the data in this study is normally distributed.

The autocorrelation test aims to test whether in the linear regression model there is a correlation between the confounding errors in period $t$ and the disturbing errors in period $t-1$ (Ghozali, 2016: 107). The autocorrelation test is assessed by using the Durbin-Watson value. If the criteria obtained is $d_{u}<d w<4-$ $d_{u}$, thus the research model is said to be free from autocorrelation. The result of the autocorrelation test of this research is presented in Table 4 below.

Table 4. Autocorrelation Test Results

\begin{tabular}{cccccc}
\hline Model & $\mathrm{R}$ & R Square & $\begin{array}{c}\text { Adjusted } R \\
\text { Square }\end{array}$ & $\begin{array}{c}\text { Std. Error of the } \\
\text { Estimate }\end{array}$ & $\begin{array}{c}\text { Durbin- } \\
\text { Watson }\end{array}$ \\
\hline 1 & 0.259 a & 0.067 & 0.058 & 0.0133 & 2.100 \\
\hline
\end{tabular}

Source: Research Data, 2018

Based on the result of the autocorrelation test in Table 4 , the durbinwatson $(\mathrm{dw})$ value of the research is 2,100. Based on the value of $\mathrm{n}=109$ and $\mathrm{k}=$ 1 , and the value of $d_{u}=1.7062$ so it is also obtained the value of $4-d_{u}=2.2938$. The criteria formulated is $1.7062<2.100<2.2938$, will fulfill the $d_{u}<d w<4-d_{u}$ criteria requirement. This shows that the data in this research is free from autocorrelation.

The heteroscedasticity test aims to test whether in the regression model there is occurrence of variance inequality of the residuals of one observation to another observation. The glejsertest can be done to detect the presence or absence 
of heteroscedasticity. The research model is said to be free from heteroscedasticity if the independent variables do not have a significant effect on the absolute residuals. The result of the heteroscedasticity test of this research is presented in Table 5 below.

Table 5. Heterocedasticity Test Results

\begin{tabular}{|c|c|c|c|c|c|c|}
\hline & \multirow[t]{2}{*}{ Model } & \multicolumn{2}{|c|}{$\begin{array}{l}\text { Unstandardized } \\
\text { Coefficients }\end{array}$} & \multirow{2}{*}{$\begin{array}{c}\begin{array}{c}\text { Standardized } \\
\text { Coefficients }\end{array} \\
\text { Beta }\end{array}$} & \multirow[t]{2}{*}{$\mathrm{t}$} & \multirow[t]{2}{*}{ Sig. } \\
\hline & & B & Std. Error & & & \\
\hline \multirow{2}{*}{1} & (Constant) & 0,011 & 0,002 & & 6,198 & 0 \\
\hline & Disclosure CSR & $-0,003$ & 0,006 & $-0,052$ & $-0,539$ & 0,591 \\
\hline
\end{tabular}

Source: Research Data, 2018

Based on Table 5, the Sig. value of the independent variable (corporate social responsibility disclosure) is 0.591 . This value is greater than 0.05 , which means there is no effect of the independent variable on the data's absolute residual. Thus, the research model does not contain symptoms of heteroscedasticity.

This research uses the simple linear regression to determine the effect of corporate social responsibility disclosure on firm risk. The results of the simple linear regression for this research can is presented in Table 6 below

Table 6. Simple Linear Regression Analysis

\begin{tabular}{llccccc}
\hline \multirow{2}{*}{ Model } & \multicolumn{2}{c}{$\begin{array}{c}\text { Unstandardized } \\
\text { Coefficients }\end{array}$} & $\begin{array}{c}\text { Standardized } \\
\text { Coefficients }\end{array}$ & \multirow{2}{*}{$\mathrm{t}$} & \multirow{2}{*}{ Sig. } \\
\cline { 3 - 5 } & $\mathrm{B}$ & Std. Error & Beta & & \\
\hline \multirow{2}{*}{1} & (Constant) & 0.037 & 0.003 & & 14.086 & 0.000 \\
& Disclosure CSR & -0.026 & 0.009 & -0.259 & -2.776 & 0.006 \\
\hline
\end{tabular}

Source: Research Data, 2018

Based on Table 6, it can be concluded that: the constant value of 0,037 shows that if the corporate social responsibility disclosure value is equal to zero, then the value of firm risk will be 0.037 , and the value of the corporate social responsibility disclosure regression coefficient of -0.026 shows that every 1 percent increase of corporate social responsibility disclosure will cause a 0.026 percent decrease of firm risk.

The simple linear regression analysis observes the goodness of fit (match test) by looking at the model feasibility test ( $F$ test), determination coefficient $\left(R^{2}\right)$, and hypothesis test ( $\mathrm{t}$ test).

The model feasibility test ( $F$ test) aims to test whether the regression model used in this study is feasible or not. The F test was carried out by looking at the significance values in the ANOVA table with the SPSS assistance program. If the significance value of ANOVA $<a$, then the model in this study is said to be feasible. The result of testing the feasibility of the model of this research is presented in Table 7 below.

Table 7. Model Feasibility Test Results (F)

\begin{tabular}{llrrrrr}
\hline \multicolumn{1}{c}{ Model } & Sum of Squares & \multicolumn{1}{c}{ df } & Mean Square & F & Sig. \\
\hline \multirow{4}{*}{1} & 0.001 & 1 & 0.001 & 7.707 & $0.006^{\mathrm{b}}$ \\
Regression & 0.019 & 107 & 0.000 & & \\
Residual & 0.020 & 108 & & & \\
Total & & & & & \\
\hline
\end{tabular}

Source: Research Data, 2018 
Based on the results of the model feasibility test in Table 7 above, the value of the $F$ test is 7.707 with the Sig. F of 0.006 which is smaller than the value of $\alpha=0.05$. This shows that the equation model in this research is feasible.

The coefficient of determination analysis is used to measure how far the ability of all independent variables in explaining the variation of the dependent variable (Ghozali, 2016: 95). In this study the coefficient of determination can be reflected by the adjusted $R$ square value. The greater the value of the adjusted $R^{2}$, the better the model and the greater the influence of the independent variable variance in explaining the variance of the dependent variable. The value of the adjusted $R$ square in this research is presented in Table 8 below.

Table 8. Determination Coefficient $\left(\mathbf{R}^{2}\right)$

\begin{tabular}{ccccc}
\hline Model & $\mathrm{R}$ & R Square & Adjusted R Square & Std. Error of the Estimate \\
\hline 1 & 0.59 & 0.067 & 0.058 & 0.0133349 \\
\hline Source: Research Data, 2018 & &
\end{tabular}

Based on Table 8 above, the adjusted $\mathrm{R}$ square value of this research is 0,058 , which means that $5.8 \%$ variation in changes in firm risk can be explained by corporate social responsibility disclosure. While the remaining 94.2 $\%$ is affected by other variables outside of the regression model in this research.

The $t$ statistic test is to find out how the independent variable partially affects the dependent variable. The criteria of this test is if the significance value of $t$ is $>0.05$ then there is no partial effect of the independent variable on the dependent variable, and vice versa if the significance value of $t$ is $<0.05$, there is a partial effect of the independent variable on the dependent variable. . The result of the hypothesis test ( $t$ test) of this research can is presented in Table 9 below.

Tabel 9. Hypothesis Test Results (t test)

\begin{tabular}{|c|c|c|c|c|c|c|}
\hline & \multirow{2}{*}{ Model } & \multicolumn{2}{|c|}{$\begin{array}{l}\text { Unstandardized } \\
\text { Coefficients }\end{array}$} & \multirow{2}{*}{$\begin{array}{c}\begin{array}{c}\text { Standardized } \\
\text { Coefficients }\end{array} \\
\text { Beta }\end{array}$} & \multirow[t]{2}{*}{$t$} & \multirow{2}{*}{ Sig. } \\
\hline & & B & Std. Error & & & \\
\hline \multirow{2}{*}{1} & (Constant) & 0,037 & 0,003 & & 14,086 & 0,000 \\
\hline & CSR Disclosure & $-0,026$ & 0,009 & $-0,259$ & $-2,776$ & 0,006 \\
\hline
\end{tabular}

Source: Research Data, 2018

The results of this test indicate that the significance value of the $t$ test for the corporate social responsibility disclosure variable is 0.006 , which is smaller than 0.05 , with a negative regression coefficient value of -0.259 . Based on these results obtained from the data analysis, it can be concluded that the research hypothesis is accepted, and corporate social responsibility disclosure has a negative effect on firm risk.

The hypothesis test results indicate that the more disclosure of economic, social, and environmental information carried out by a company, the lower the risk of the firm. Cheng \&Christiawan (2011) stated that the disclosure of company activities related to CSR can send positive signals to the market and company's stakeholders regarding the prospects of the company's sustainability in the future. Suharto (2007) stated that the implementation of CSR is used by company management as a risk management strategy. This is supported by Jo et al., (2016) who stated that CSR initiatives of firms are generally associated with 
additional risk reduction. Companies with CSR disclosure on an ongoing basis can improve the company's image (Bhernadha, Topowijono, \& Azizah, 2017), because companies that have implemented and disclosed CSR activities show that the company pays attention to the social and environmental impacts of its operational activities. Kapita \& Suardana (2018) stated that the better disclosure of corporate social responsibility within the company would tend to improve the company's reputation. This causes stakeholders' trust to increase, so that these stakeholders will support the existence and operations of the company. The support and trust of these stakeholders strengthens the sustainability of the company, which in turn will reduce the firm risk in the future. A CSR program in a company, indicates that the company has a commitment in maintaining good relations with the environment, social and surrounding communities, so that it can be an indicator in determining the company's business stability, and can reflect the low risks that may be experienced by the company in the future.

The result of this research are supported by the results of the research conducted Cai et al., (2016), Jo et al., (2016), Albuquerque et al., (2014), Jo \& Na (2012), and Salama et al., (2011) which states that information regarding corporate social responsibility has a negative effect on firm risk.

\section{CONCLUSIONS AND SUGGESTIONS}

Based on the discussion of the result of the research, it can be concluded that the more disclosure of corporate social responsibility information by a company, the lower its firm risk. This result can be obtained because management of companies use positive information disclosure, such as information on CSR, as an effort to reduce firm risk. The reduction of risk is caused because CSR information disclosure is used as a positive signal regarding the performance and operations of the company, which can enhance the company's reputation in stakeholders' eyes, so that the company obtains support and trust from stakeholders, and increases the legitimacy of the organization, which is important for the sustainability of the company in the future.

Based on the results, discussion and conclusion of this research, the suggestions that can be given in this research, are: future researchers can add other variables that may affect firm risk, use other proxies that can represent firm risk and corporate social responsibility disclosure better, and expand the research area into all companies in Indonesia Stock Exchange (IDX). It is recommended for company management in Indonesia to put more attention on the importance of the disclosure of CSR information in managing firm risk, as well as increasing the quality and quantity of social and environmental information disclosure. Stakeholders should pay more attention to the corporate social responsibility disclosure of companies and use this information as one of the considerations in making decisions. It is suggested that regulators in Indonesia should develop clearer regulations and standards regarding CSR disclosure in Indonesia. 


\section{REFERENCES}

Aghashahi, B., Rasid, S. Z. A., Sarli, M., \& Mand, A. A. (2013). Corporate Social Responsibility Reporting of Food Industry Major Players. Interdisciplinary Journal of Contemporary Research In Business.

Albuquerque, R. A., Koskinen, Y., \& Zhang, C. (2011). Corporate Social Responsibility and Firm Risk: Theory and Empirical Evidence (Working paper. Boston University.). https:// doi.org/10.2139/ssrn.1961971

Albuquerque, R., Durnev, A., \& Koskinen, Y. (2014). Corporate Social Responsibility and Firm Risk: Theory and Empirical Evidence.

Anjani, N., \& Astika, I. B. P. (2018). Pengaruh Pengungkapan Corporate Social Responsibility pada Nilai Perusahaan dengan Likuiditas Perusahaan sebagai Pemoderasi. E-Jurnal Akuntansi Universitas Udayana, 24(2), 899-92. https://doi.org/https://doi.org/10.24843/EJA.2018.v24.i02.p04

Astuti, C. W., \& Nugrahanti, Y. W. (2015). Pengaruh Pengungkapan Corporate Social Responsibility terhadap Reaksi Pasar. Dinamika Akuntansi, Keuangan Dan Perbankan, 4(2), 90-105.

Ben-Horim, M., \& Levy, H. (1980). Total Risk, Diversifiable Risk and Nondiversifiable Risk: A Pedagogic Note. The Journal of Financial and Quantitative Analysis. https://doi.org/10.2307/2330346

Bhernadha, Y. A., Topowijono, \& Azizah, D. F. (2017). Bhernadha, Y. A., Topowijono, \& Azizah, D. F. (2017). Pengaruh Corporate Social Responsibility terhadap Kinerja Keuangan Perusahaan. Jurnal Administrasi Bisnis (JAB), 44(1), . Jurnal Administrasi Bisnis (JAB), 44(1), 134-143. Retrieved from

http://administrasibisnis.studentjournal.ub.ac.id/index.php/jab/article/vi ew $/ 1738$

Branco, M. C., \& Rodrigues, L. L. (2008). Factors influencing social responsibility disclosure by Portuguese companies. Journal of Business Ethics, 83(1), 685701. https://doi.org/10.1007/s10551-007-9658-Z

Brigham, E. F., \& Houston, J. F. (2013). Dasar-Dasar Manajemen Keuangan (Fundamentals of Financial Management (11th ed.). Jakarta: Salemba Empat.

Cai, L., Cui, J., \& Jo, H. (2016). Corporate Environmental Responsibility and Firm Risk. Journal of Business Ethics, 139(3), 563-594. https:/ / doi.org/10.1007/s10551-015-2630-4

Cheng, B., Ioannou, I., \& Serafeim, G. (2014). Corporate social responsibility and access to finance. Strategic Management Journal, 35(1), 1-23. https://doi.org/10.1002/smj.2131

Connelly, B. L., Certo, S. T., Ireland, R. D., \& Reutzel, C. R. (2011). Signaling theory: A review and assessment. Journal of Management, 37(1), 39-67. https:// doi.org/10.1177/0149206310388419

Cui, J., Jo, H., \& Na, H. (2016). Does Corporate Social Responsibility Reduce Information Asymmetry? Journal of Business Ethics, 148(3), 549-572.

Cui, J., Jo, H., \& Na, H. (2017). Corporate Social Responsibility, Religion, and Firm Risk. Asia-Pacific Journal of Financial Studies, 46(2), 305-340. https://doi.org/10.1111/ajfs.12171

Dhaliwal, D. S., Radhakrishnan, S., Tsang, A., \& Yang, Y. G. (2012). Nonfinancial disclosure and analyst forecast accuracy: International evidence on 
corporate social responsibility disclosure. Accounting Review, 87(3), 723-759. https://doi.org/10.2308/accr-10218

Dwipayadnya, P. A., Wiagustini, N. L. P., \& Purbawangsa, I. B. A. (2015). Kepemilikan Manajerial dan Leverage sebagai Prediktor Profitabilitas dan Pengungkapan Corporate Social Responsibility. Jurnal Buletin Studi Ekonomi, 20(2), 150-157.

Elkington, J. (1998). Cannibals with forks: The triple bottom line of sustainability. Gabriola Island: New Society Publishers. https://doi.org/10.1002/tqem.3310080106

Ghozali, I. (2016). Aplikasi Analisis Multivariete dengan program IBM SPSS 23. In IBM SPSS 23. Semarang: Universitas Diponegoro.

Godfrey, P. C. (2005). The relationship between corporate philanthropy and shareholder wealth: a risk management perspective. Academy of Management Review, 30(4), 777-798.

Gray, R., Owen, D., \& Maunders, K. (1988). Corporate Social Reporting: Emerging Trends in Accountability and the Social Contract. Accounting, Auditing $\mathcal{E}$ Accountability Journal, 6-20. https://doi.org/10.1108/EUM0000000004617

Gunawan, L., \& Juniarti. (2014). Pengaruh Family Control, Firm Risk, Size, dan Age Terhadap Profitabilitas dan Nilai Perusahaan Pada Sektor Perdagangan, Jasa, dan Investasi. Business Accounting Review, 2(1), 41-50.

Halov, N., \& Heider, F. (2011). Capital structure, risk and asymmetric information. The Quarterly Journal of Finance, 1(4), 767-809.

Jo, H., Kim, H., \& Park, K. (2016). Controversial Industries , Regional Differences , and Risk: Role of CSR. In Korean Financial Society Conference, 27 Mei 2016 (pp. 1695-1756).

Jo, H., \& Na, H. (2012). Does CSR Reduce Firm Risk? Evidence from Controversial Industry Sectors. Journal of Business Ethics, 110(4), 441-456. https://doi.org/10.1007/s10551-012-1492-2

Jupe, R. (2005). Disclosure in Corporate Environmental Reports: A Test of Legitimacy Theory. (Working Paper No. 91, 1-32). Retrieved from https://core.ac.uk/download/pdf/10631384.pdf

Kapita, N. M. Y., \& Suardana, K. A. (2018). Pengaruh Pengungkapan Corporate Social Responsibility dan Good Corporate Governance Pada Reputasi Perusahaan Manufaktur. E-Jurnal Akuntansi Universitas Udayana, 24(2), 11901219. https://doi.org/https://doi.org/10.24843/EJA.2018.v24.i02.p14

Karlina, N. W. S., \& Widanaputra, A. A. G. P. (2016). Pengaruh Devidend Per Share, Return On Equity, dan Price to Book Value pada Return Saham. EJurnal Akuntansi Universitas Udayana, 15(3), 2082-2106. Retrieved from https://ojs.unud.ac.id/index.php/Akuntansi/article/view/18279

P. C. Godfrey. (2005). The relationship between corporate philanthropy and shareholder wealth: a risk management perspective. Academy of Management Review, 30(4), 777-798.

Prakasa, S., \& Astika, I. B. P. (2017). Pengaruh Leverage, Profitabilitas, Dan Kepemilikan Manajemen Pada Corporate Social Responsibility Disclosure Perusahaan Pertambangan. E-Jurnal Akuntansi, 18(1), 189-215. Retrieved from https:/ /ojs.unud.ac.id/index.php/Akuntansi/article/view/22487 
Rahayu, W., Darminto, \& Topowijono. (2014). Pengaruh Pengungkapan Corporate Social Responsibility (CSR) terhadap Profitabilitas Perusahaan. Jurnal Administrasi Bisnis (JAB), 17(2), 1-8.

Ross, S. A., Westerfield, R. W., \& Jordan, B. D. (2011). Essentials of corporate finance (7th editio). Boston: McGraw-Hill Irwin.

Sembiring, E. R. (2003). Kinerja Keuangan, Political Visibility, Ketergantungan pada Utang, \& Pengungkapan Tanggung Jawab Sosial Perusahaan. In Simposium Nasional Akuntansi VI Surabaya, 16 -17 Oktober 2003 (pp. 249-258).

Sen, S., Bhattacharya, C. B., \& Korschun, D. (2006). The role of corporate social responsibility in strengthening multiple stakeholder relationships: A field experiment. Journal of the Academy of Marketing Science, 34(2), 158-166. https://doi.org/10.1177/0092070305284978

Su, W., Peng, M. W., Tan, W., \& Cheung, Y. L. (2016). The Signaling Effect of Corporate Social Responsibility in Emerging Economies. Journal of Business Ethics, 134(3), 479-491. https:/ / doi.org/10.1007/s10551-014-2404-4

Sugiyono. (2010). Metode Penelitian Bisnis. Pendekatan Kuantitatif, kualitatif dan R \& D. Bandung: Alfabeta, 15(2010), 90. https://doi.org/10.1016/S09694765(04)00066-9

Suharto, E. (2007). Kebijakan Sosial Sebagai Kebijakan Publik: Peran Pembangunan Kesejahteraan Sosial dan Pekerjaan Sosial dalam Mewujudkan Negara Kesejahteraan di Indonesia. Bandung: Alfabeta. Retrieved from https://ojs.unud.ac.id/index.php/Akuntansi/article/view/5143

Sun, N., Salama, A., Hussainey, K., \& Habbash, M. (2010). Corporate environmental disclosure, corporate governance and earnings management. Managerial Auditing Journal, 679-700. https://doi.org/10.1108/02686901011061351

Susianti, M. N. L., \& Yasa, G. W. (2013). Pengaruh Kinerja Keuangan terhadap Nilai Perusahaan dengan Pemoderasi Good Corporate Governance dan Corporate Social Responsibility. E-Jurnal Akuntansi Universitas Udayana, 3(1), 73-91.

Retrieved from https://ojs.unud.ac.id/index.php/Akuntansi/article/view/5143

Wulandari, A. A. I. R., \& Putri, I. G. A. M. A. D. (2014). Pengaruh Informasi Laba Akuntansi Dan Informasi Corporate Social Responsibility Pada Return Saham. E-Jurnal Akuntansi Universitas Udayana. E-Jurnal Akuntansi Universitas Udayana, 7(2), 462-476. 